\title{
Preventive, Palliative, or Punitive? Safe Spaces in Bosnia-Herzegovina, Somalia, and Sri Lanka
}

\author{
JENNIFER HYNDMAN \\ Department of Geography, Simon Fraser University
}

\begin{abstract}
Some safe havens and protected areas are safer than others for internally displaced persons situated in war zones. The research presented compares three such areas: the 'safe cities' of Bosnia-Herzegovina, a UN-sanctioned 'preventive zone' in Southern Somalia, and an 'open relief centre' in Northern Sri Lanka. Each of these safe spaces has distinct political antecedents, peacekeeping components, and histories prior to war that have shaped the success of such areas in protecting people during conflict. In comparing the safety and well-being of displaced civilians in the three countries, the importance of consent by warring parties to the international designation of safe space emerges as critical. The authorization of a chosen safe area, by the UN Security Council or by warring factions, plays an important role in relation to its efficacy. The research presented suggests that zones of peace and protected areas cannot solely be enforced by international peacekeepers, but must be negotiated at a political level.
\end{abstract}

At the time of writing this paper, the city of Srebrenica in Bosnia-Herzegovina marks the seventh anniversary of the massacre there in July 1995. After more than a decade of conflict in Somalia, instability continues and has been fuelled anew since September 112001 with allegations that Al-Qaeda cells may be based in the country. The Sri Lankan Government, after two decades of war, is moving extremely cautiously towards peace negotiations with the Liberation Tigers of Tamil Eelam (LTTE), led by Vellupillai Prabhakaran. What, if anything, do these disparate parts of the world have in common, except for the legacies of war? All have been sites of experiment in which different kinds of safe spaces were created to protect displaced persons within their home countries. Some fared better than others, though the distinctive circumstances precipitating each crisis and the specific safe space implemented are not strictly comparable. This article attempts to trace the antecedents and outcomes of each of these spaces, acknowledging that all are part of a strategy of de facto containment that characterizes humanitarian responses since the early 1990s (Frelick 1993; Hyndman 2000; Duffield 2002). It is argued here that the historical connotations of places designated as safe by international bodies are critical to their success, raising obvious questions about the concept of enforced safe spaces. Not 
surprisingly, internationally ascribed safe areas designated for civilians in war zones are most likely to work where first, warring factions consent to them; and second, the designated area has local connotations of sanctuary or safety. These basic conditions have not always been met (Outram 1997).

Safe spaces, as internationally-sanctioned zones of protection for displaced civilians, are a reasonably recent, post-Cold War phenomenon. In 1991, the UN Operation Provide Comfort in Northern Iraq was the first UN-sanctioned international intervention into a sovereign state. Some 400,000 Iraqi Kurds, fleeing the violence of Saddam Hussein's forces, approached the Turkish border where they were not welcome. In an unprecedented move, the UN Security Council passed Resolution 688 creating a 'safe haven' in Northern Iraq. Protected by international peacekeepers on the ground, and a 'no fly zone' in the air space above, Operation Provide Comfort was-in hindsightprobably the most effective of the safe haven attempts undertaken. After this initial foray, 'the standard of safety in such zones steadily declined' (Frelick 1999: 24). From Iraq to Haiti to Rwanda, distinct safe areas have been deployed with disparate results and to different ends. If safe spaces are more 'rhetoric than reality' (Frelick 1999: 25) as some critics claim, why have they been used so often by international bodies mediating the consequences of war? Why are some safe areas more effective than others? What political, legal, and geographical dimensions generate such spaces?

This paper analyses the meanings, outcomes, and geographies of three distinct safe spaces in Somalia, Bosnia-Herzegovina, and Sri Lanka. Each of these sites is situated within a unique context of war; the historical and geographical contingencies of conflict must be considered in any comparison among them. The humanitarian discourse of 'preventive protection' and 'the right to remain' has generated many, but not all, of the safe spaces within conflict areas in the 1990s. This language of humanitarian assistance emerged as a highly spatialized project of reorienting human displacement closer to home (Hyndman 2000). Since the UN intervention in Iraq, crossing an international border and claiming asylum as a refugee is no longer the only way to receive assistance or protection from the international humanitarian regime. In this new millennium, both humanitarian and development aid are increasingly deployed at or near sites of conflict:

Rather than patronize Third World political entities the trend today is to join metropolitan public-private humanitarian alliances and aid regimes designed to contain and neutralize what is now interpreted as international stability. From support, the trend is towards containment, management and eradication (Duffield 2002: 76).

The meaning of 'refugee' has changed dramatically since the end of the Cold War, and its value in geopolitical terms has clearly declined. Where refugees once provided proof of Western superiority in the rivalry with the USSR, they are increasingly considered more of a liability when they cross international borders. Political support for hosting refugees has reached its limits among 
many governments in countries receiving asylum seekers. As Newland (1999: 17) notes, 'a determination was made to bring safety to people rather than people to safety, by force if necessary'. The strategy of helping people internally displaced within their home countries is both a political and practical one that has met with mixed results. One goal of this paper, then, is to trace the way in which these safe areas have been established, ascertain their actual safety, and determine why some are more effective than others. Whether the safe areas are predicated on legal or political grounds, and at local or international scales, will appear to make all the difference.

The analysis presented is not strictly comparative, that is, the approaches taken to glean insights about each of these sites were distinct as were their political circumstances. Field visits to safe areas in Somalia, Sri Lanka, and Bosnia took place over a period of seven years, under different circumstances of war and peace, and in different research capacities. My access to these areas varied considerably. In Somalia in 1993, I worked for UNHCR as a field officer for the Cross-Border Operation based in the 'preventive zone' in the southern (Bai-Gedo) region of the country, returning again to the region in 1994-1995 as a researcher. In 1999, my fieldwork in Bosnia-Herzegovina was circumscribed by the aftermath of the NATO bombing in the Federal Republic of Yugoslavia. As someone from a NATO country, I did not visit Srebrenica, located in what is now the predominantly Serb, Republika Srpska. I focused my fieldwork instead in Sarajevo and Gorazde. In Sri Lanka, my work on a separate research project took me through much of the northern and eastern parts of the country, including to Madhu. The information analysed in the paper derives from field notes made during visits to each of these locations based on interviews with local staff in UN agencies, non-governmental organizations (NGOs), and other contacts. I also analyse newspaper reports, evaluations of operations, and a number of secondary sources.

\section{Safe Spaces as Strategic}

The 1990s witnessed a respatialization of responses to crises of human displacement. Solutions that addressed the problem as close to home as possible were preferred for both political and economic reasons. The major players in this regime, namely donor governments of the most industrialized countries, shifted their emphasis from 'the right to leave' one's country in the face of persecution or violence to 'the right to remain'. Displaced people were, and still are in many cases, encouraged to stay within their countries of origin by providing assistance to them there, rather than having them seek protection through asylum across an international border. Some policy analysts contend that the concept violates the right to leave one's country and to seek asylum as outlined in the UN Declaration of Human Rights. Others argue that several of these safe havens or protected zones have not been safe at all. 'New spatial categories, like the concept of Safety Zones, must therefore necessarily be 
deconstructed in the matrix of changing configurations of material and social processes' (Chimni 1995: 823).

Srebrenica, a mainly Muslim town in eastern Bosnia-Herzegovina, was designated a 'safe haven' by the UN Security Council in a resolution passed on 16 April 1993. The Security Council added five more 'safe areas', all with predominantly Muslim populations, in a second resolution on 6 May 1993. A third resolution, passed on 4 June 1993, authorized air strikes to protect the six areas' UN defenders. Despite these measures, Bosnian Serb forces entered Srebrenica in July 1995, following which some 7,000-8,000 Muslims, mainly men or boys, were murdered. Unlike the safe havens of Sarajevo, Gorazde, and Bihac which had large Bosnian army forces, Srebrenica was mostly demilitarized. Consequently, Serbs were able to take over the town with little resistance. The small battalion of Dutch peacekeepers left the town when their air cover did not arrive, and they realized the futility of their presence (HINA news agency 1998).

By the end of the decade's experiments in safe areas, experts in humanitarian law and operations articulated incisive questions about the viability of such protected zones, yet they had few answers. Sergio Vieira de Mello, then UnderSecretary General for Humanitarian Affairs at the UN Office for the Coordination of Humanitarian Affairs (OCHA) and recently appointed UN High Commissioner for Human Rights, noted that the idea of protected areas raises as many questions as it appears to resolve. Such questions include:

- Whether the idea of establishing a protected area based on consent is realistic?

- Whether the establishment of a protected area using international force can be effective?

- Whether the creation of such areas might contribute (unwittingly) to ethnic cleansing?

- To what extent the creation of a protected area undermines the right to asylum?

- To what extent might the creation of such an area permanently influence international borders?

- To what extent does the construction of such an area affect the treatment of civilians outside the area? (UN OCHA 1999: 2)

What is most interesting about these questions is that they could only be asked in hindsight, after experiments in deploying safe spaces had been tried with mixed results. If these questions could have been posed and answered at the beginning of the 1990s, the pattern of humanitarian response might well have looked very different.

The shift in discourse from 'the right to leave' and 'the right to seek asylum' to 'the right to remain' generated a set of safe areas within conflict-affected areas. These came into being as a result of UN Security Council resolutions during the 1990s that contested the idea that sovereignty is sacrosanct where governments fail to protect the basic rights and safety of certain groups of 
citizens. 'Preventive protection' designates a set of highly spatialized management practices for people out of place, literally those forced to flee their homes. While the establishment of 'safe havens' for Iraqi Kurds in Northern Iraq in 1991 is said to mark this turning point, 'open relief centres' for would-be Sri Lankan refugees, and 'safe corridors' to Muslim enclaves in Bosnia, have also been an expression of this respatialization of humanitarian response. Humanitarian law as codified in the Geneva Conventions has long defined another set of safe spaces, including hospitals for combatants and agreed treatment for prisoners of war. Other, equally conventional safe spaces, namely refugee camps, have also played an important role in providing sanctuary for displaced persons, though even the safety of camps has come under question since the Rwanda genocide of $1994 .^{1}$

\section{UN Perspectives on Safe Areas}

The expert consultation organized by OCHA and the Harvard Center for Population and Development Studies in February 1999 generated important insights and new terminology around the concept of safe spaces. From the outset, the geographical and historical contingency of protection was identified: 'The concept of protection was recognized to be sensitive to elements of place (i.e., terrain, climate, geographic location) size (i.e., population, spatial area), time (i.e., duration, stage of conflict) and overlapping regulatory regimes' (UN OCHA 1999: 5). Despite this important introductory observation, little genuine analysis of the local political context of safe areas was undertaken. Rather, a familiar debate between advocates of humanitarian law versus those of humanitarian operations authorized by the UN Security Council resolutions ensued. This tension between legal and political approaches to complex emergencies had the effect of foreclosing debate around these seemingly mutually exclusive options.

At the consultation, the very meaning of humanitarian protection was debated at length, with participants citing competing references to prevention in humanitarian law and in practice (UN OCHA 1999). Preventive protection defined in relation to international humanitarian law is contractual and based on consent by warring parties that agree to render designated areas of medical treatment 'off limits.' In contrast, preventive protection in the operational sense has referred to the designation of safe spaces by UN authorities enforced by military power, usually in the form of peacekeepers. This distinction between consensual 'protected zones', based in international humanitarian law, and 'safe areas', specified by the UN Security Council but not necessarily agreed to by warring factions, is a crucial one. The participants in the consultation determined that consensual safe areas should be called 'humanitarian zones' and the UN-designated sites 'security zones', a terminology that suggests a distinction between legal and politically-driven safe areas. Yet, as before, there is little recognition of local patterns of protection or customary places of sanctuary. Protection in both the legal and political sense is assumed to be the 
domain of warring parties, international actors and instruments. The experts recognized "the need to "manage" consent and to try to preempt its erosion or withdrawal' (UN OCHA 1999: 18). ${ }^{2}$ A more comprehensive consultation with civil society actors, as difficult as it might be in a war zone, might have generated valuable and innovative insights. ${ }^{3}$

This top-down approach to protection excludes local information, such as historical patterns of dealing with insecurity and the meanings attached to particular sites in an area of displacement. An approach that attends to the cultural politics, geopolitics, and history of a place emerges between these legal and political approaches. Civilian protection during war cannot rely solely upon contractual legal obligations forged on an international scale, nor can the security of states prevail over the security of people if genuine protection is the aim. Civilian security involves a finer scale of analysis and action, and a broader sense of what constitutes security (DFAIT 2000). The geopolitical context and historical relation of particular groups to specific areas was not part of the puzzle experts addressed when they took inventory of UN protected areas, although they did identify as a topic for further study the 'need to explore ad hoc consensual solutions outside the traditional normative framework, e.g., Open Relief Centers in Sri Lanka' (UN OCHA 1999: 18).

Of the safe areas covered here, the most controversial has been the setting up of the UN-protected areas in Bosnia-Herzegovina. In retrospect, it is ironic that UN authorities were able to achieve a negotiated agreement with the Bosnian Serbs on Srebrenica as a 'safe' city, but not on Sarajevo and Gorazde. In practice, this form of agreement meant little: Srebrenica was attacked and much of its male population massacred. Sarajevo and Gorazde were also hit hard, but were able to stave off the offensives more successfully due to more sizeable fighting forces. The experts at the February 1999 meeting agreed that the 'safe city' tactic should be a strategy of last resort in locations where no trust or respect for international humanitarian law can be established. Security zones are not economically feasible; generate unavoidable dependency on international assistance; and have the potential to create 'a largely vacant landscape dotted with small, unsustainable protected areas' (DFAIT 2000: 8). Concern was voiced that protected areas were represented as 'empty spaces' that failed to take account of the socio-political relations and organizations of civil society in situ. Such mapping practices echo imperial cartographies that have long served to obfuscate the presence of (indigenous) peoples and the political importance of their struggles (Sparke 1995; Harley 1992).

Adding further to the critique of safety (or security) zones, Chimni (1995) examines the deployment of the first such safe space authorized by the UN Security Council in Iraq during the 1991 displacement of Kurdish Iraqis. Not only did the Security Council exceed its authority in passing resolution 688, which established the safe havens, but the resolution 'served to legitimize Turkey's decision to close its border and [....] an undesirable precedent had thereby been set' (Suhrke cited in Chimni 1995: 837). In coming to the aid of Turkey, which faced the prospect of a sizeable and undesirable Kurdish refugee 
population, the Western coalition demonstrated solidarity with its geopolitical ally as much as it assisted the would-be refugees as internally displaced persons inside Northern Iraq. Having said this, the safe havens in Iraq were the most successful of the security zone experiments that took place in the 1990s.

The next section turns to Bosnia-Herzegovina, where the experiment in safe spaces went seriously awry. It traces the terrain of conflict and displacement, the politicization of the humanitarian project, and the violation of protection provided by the safe haven of Srebrenica in particular.

\section{Bosnia-Herzegovina}

Between 1992 and 1995, brutal and systematic campaigns of ethnic cleansing in Bosnia displaced more than half the population (Cutts 1999). By the end of the war, almost a million people were refugees in other countries while 1.3 million people, out of the area's pre-war population of 4.3 million, were internally displaced. Subsequently, hundreds of thousands of people became dependent on humanitarian aid, especially in the designated safe havens where flight to these cities and towns left large parts of the countryside abandoned.

The causes of the war are much more difficult to recite, and a comprehensive treatment of its dynamics is precluded here. However, claims to the territory of Bosnia-Herzegovina took on a renewed urgency after the European Union recognized the secession of the republics of Slovenia and Croatia from the state of Yugoslavia in 1991. Bosnia-Herzegovina had little choice but to declare its own independence from Belgrade. It would have otherwise become a largely non-Serbian republic within an increasingly Serb-dominated federation, or it would have to accept the division of Bosnia between Serbs and Croats, as proposed by their respective leaders. Bosnia's ethnic composition before the war was approximately 44 per cent Muslim, 31 per cent Serb, 17 per cent Croat, and 6 per cent Yugoslav with a small residual population (Campbell 1999). ${ }^{4}$ Bosnia's declaration of independence was, of course, contested by the Serb-dominated army of Yugoslavia under the control of Slobodan Milosevic and by the president of Croatia, Franjo Tudman; over 60 per cent of Yugoslavia's military industries were based in Bosnia, 60 per cent of which were located in Croat or Muslim regions (Glenny 1992: 150). Croats and Serbs continued to fight by proxy in and over Bosnia-Herzegovina. As Glenny explains:

The essential problem of a Yugoslav state lies in the numerical and political dominance of Serbs over Croats; the essential problem of a Croatian state lies in the numerical and political dominance of Croats over Serbs. In order to secure peace in the Balkans, this conundrum must be solved along with two others: the constitution of Bosnia-Herzegovina and in Serbia, the political status of the Moslem, Albanian and Hungarian minorities in the Sandzak, Kosovo and Vojvodina, respectively (1992: 100). 
According to Glenny, the end of Bosnia began on the weekend of 1 March 1992 when the European Union announced that its independence would be recognized.

Between May 1992 and November 1995, the UN Security Council passed 46 resolutions concerning the situation in Bosnia-Herzegovina (Cutts 1999). What is significant about the establishment of the safe cities is that the 'host' state endorsed the proposal (Chimni 1995). The fledgling state's aim was to maintain as many people as possible to oppose Serb aggression and to keep the Bosnian economy afloat by retaining productive Bosnians in the country. As Chimni (1995) asks, in reference to state endorsement of the safe cities, does a state have the right to prevent people from fleeing persecution beyond the borders of the state even when the objective is the survival of the state? This question highlights the divergence in interests between the security of precarious, emerging states and the security (or protection) of their citizens. The interests of states clearly prevailed in this case, although the Security Council did authorize both humanitarian and peacekeeping missions to Bosnia to ensure the delivery and distribution of humanitarian assistance. The UN Protection Force, UNPROFOR, was assigned as the peacekeeping mission to Bosnia, while UNHCR was designated the lead agency for humanitarian operations. This was the first time that UNHCR had worked directly in a conflict zone (Cunliffe and Pugh 1997).

Two UN Security Council resolutions ( 824 and 836 ) created the basis for the 'safe areas' of Srebrenica, Sarajevo, Tuzla, Zepa, Gorazde, and Bihac. All of these centres hosted a majority Bosnian Muslim population, but cities like Tuzla and Sarajevo were renowned for their multi-ethnic character. According to a UNHCR contact, this mixing of cultures has changed dramatically. Postwar Sarajevo is 80 per cent Muslim, 5 per cent Croat, and 15 per cent Serb. Bihac, a mainly Muslim town located in the northwest corner of Bosnia, was surrounded by Serb-held territory before the war, but the selection of Bihac as a protected area belies an important political history. The Bihac-Cazin region has long featured a Muslim enclave amid a largely Serb population which straddles both Bosnian and Croatian territory. Prior to the war, an alliance between Muslims and Serbs existed here since World War II. Bihac proved to be one of the safer UN protected areas during the war, despite it becoming the capital of Bosnian Serb nationalism.

\section{Sampling Safe Cities in Bosnia-Herzegovina}

In 1994, a market massacre in Sarajevo in February was followed by a major Serb offensive in Gorazde in April, this despite the 'safe city' designation. The siege of Sarajevo has become seared in the minds of many, thanks to extensive media coverage of the violence. Michael Winterbottom's $1997 \mathrm{film}$, Welcome to Sarajevo, captures the gendered spaces of brutality, borrowing from live footage shot during the war. It illuminates the rape camps in which men from enemy ethnic groups raped women and then forced them to carry the 
pregnancies; prison camps in which men of fighting age were literally starved; and underground spaces where other men of fighting age hid from the authorities and the prospect of conscription into a senseless war. Scores of people died along 'sniper's alley' and throughout the city, even during Sarajevo's tenure as a UN-designated 'safe city.'

From the start, the concept of the safe cities in Bosnia-Herzegovina was criticized on the grounds that by concentrating vulnerable civilians in specified cities, the UN unwittingly created a target for aggressors and participated in a humanitarian exercise that inadvertently ethnically cleansed large tracts of rural territory now available to these same aggressors. Not until July 1995 was it fully evident that the flawed concept of safe cities could be equally flawed and even fatal in terms of the practical protection it could afford displaced civilians.

As noted, Srebrenica is the most notorious and was the most dangerous UNdesignated 'safe space'. It is also the least normalized of all the former safe cities in post-conflict Bosnia. Local (Serb) authorities in Srebrenica (now located in Republika Srpska) have refused to allow Bosniaks (Bosnian Muslims) back into Srebrenica, a town once 95 per cent Muslim and 5 per cent Serb. In June 1999, local Serb nationalists finally allowed the majority Muslim town council, elected more than two years before in absentia, to take office (Rhode 1999). Bowing to international pressure and local economic realities, Serbian nationalists have nonetheless used endless negotiations, administrative bureaucracy, rock-throwing, and other tactics to prevent the Muslim town councillors from meeting and to prevent Muslim refugees from returning to their homes. Most of the 12,000 Serbs who inhabit Srebrenica are refugees from Sarajevo, the city that ironically hosts most of the refugees who survived Srebrenica. Because of a multi-year embargo by the US and EU nations, most international aid has bypassed Srebrenica in response to Serb recalcitrance. The return process is fraught not only with insecurity for those returning as minorities, but also the fear of unemployment and increased poverty (Hovey 2001). Unemployment among people of minority backgrounds far exceeds the national average of $45-60$ per cent.

In the broader national context of Bosnia, two critical sets of conditions served to destabilize the safe cities of Bosnia. First, 'UNPROFOR was singularly unsuccessful at improving access for humanitarian organizations to the government enclaves which were besieged by Bosnian Serb authorities' (Cutts 1999: 9). Mark Cutts, who was Head of the UNHCR office in Sarajevo during much of the war, explains that this arrangement was the outcome of an arrangement in which UNPROFOR itself depended entirely on authorization from the Bosnian Serb authorities to travel through its territory. Thus, permission to travel to the safe areas in order to protect displaced civilians was sought from the very forces who threatened their safety. When Bosnian Serbs cut off humanitarian access to Sarajevo, food and medical supplies fell to dangerously low levels, despite the UN airlift. ' $[\mathrm{A}]$ ssistance was in fact provided on the basis of accessibility rather than on the basis of needs' (Cutts 1999: 25; emphasis in original). 
Second, while UNPROFOR's peacekeeping position was less than optimal, UNHCR's humanitarian mission also encountered problems detrimental to the safe areas. As the lead civilian agency, UNHCR became politicized by forces beyond its control. Technically an apolitical agency, UNHCR's role in the conflict was increasingly seen as political rather than humanitarian as it negotiated the proportional distribution of humanitarian goods and appeared, at times, to be in charge of protecting Bosnian Muslims. 'This process [of politicization] was compounded in three ways: the absence of international political will; the financial and political pressures imposed upon UNHCR's operational environment; and the blurring of the humanitarian and military operations' (Cunliffe and Pugh 1997: 137-138). Given UNPROFOR's reliance on Serb officials for permission to travel, UNHCR's reliance on UNPROFOR for aid convoys meant that it fell prey to similar problems. All these pressures 'have coincided with emphasis upon "country of origin solutions" to eradicate the causes of refugee flight' (pp. 141-142). Not only did UNHCR have limited direct representation in the UN protected areas, but the agency could not ensure the protection of basic rights and had little control over the physical protection of civilians in the region. Ethnic cleansing proved to be one of the biggest conundrums for UNHCR. Could they evacuate civilians who were under threat but who had not yet fled? Or was that aiding and abetting the enemy by helping it to ethnically cleanse the areas under siege? 'While UNHCR was able to deliver large quantities of humanitarian supplies during the war, it was much less successful in carrying out its protection mandate' (Cutts 1999: 16). The provision of humanitarian assistance substituted for protection.

\section{Somalia}

In January 1991 Somalian President Siad Barre was ousted from power. By 1992, civil conflict had become widespread and had induced famine in several parts of the country. Images of malnourished Somalians appeared on televisions worldwide, winning public sympathy and government donations to fund humanitarian efforts in both Somalia and Kenya. A series of refugee camps and temporary border sites were established in Kenya to accommodate Somalians as they crossed the border, most in desperate physical condition. Mortality rates soared in these ill-prepared makeshift camps until water quality, sanitation conditions, and food supplies could be stabilized.

In December 1992, the US-led Operation Restore Hope landed in Somalia, ostensibly to save the country from itself. Perhaps the most vivid testimony of prevention was the passing of UN Security Council Resolution 794 which authorized a Unified Task Force (UNITAF) of thousands of peacekeeping troops to enter Somalia so that relief supplies could be safely delivered. 'Operation Restore Hope', as the mission was called, was the first peacekeeping operation which intervened in a sovereign member state when that state did not present a military threat to its neighbours (Makinda 1993). This move 
challenged the sovereignty of states by entering a country in the absence of an external threat. Somalian society was portrayed as an anarchy imploding on itself, and humanitarian need was considered grave enough to warrant multilateral intervention (Shohat and Stam 1994). Operation Restore Hope provided the peacekeepers and military presence necessary for the establishment of the preventive zone. The initial UNITAF forces were replaced by UN (UNOSOM II) forces in May 1993.

The 'preventive zone' established in Somalia was at once a UN Security Council invention and a political panacea. The establishment of a preventive zone inside Somalia was part of a larger mission, the Cross-Border Operation (CBO), instigated late in 1992 and 'aimed at preventing new refugees and facilitating repatriation' (Kirkby et al. 1997: 181). The CBO was in large part a response to the threats of Kenyan President Daniel Arap Moi, whose reelection in December 1992 provided a political platform from which to announce the Kenyan Government's plan to return Somalian refugees-by whatever means necessary-to their country. UNHCR-sponsored refugee camps in Kenya at the time hosted hundreds of thousands of refugees, but UNHCR's work with refugees relied on the permission of the Kenyan Government. As the space in which UNHCR could operate within Kenya began to shrink, sustained efforts were made to fund an alternative 'preventive' path within Southern Somalia (Hyndman 2000). Thus, the preventive zone had a humanitarian purpose, but was produced by political exigency and a desire to repatriate refugees. At the request of the UN Secretary-General, UNHCR initiated the CBO based on the concept of a preventive zone, previously used in Afghanistan and Cambodia (Kirkby et al. 1997). Its purpose was to stem the flow of refugees from Somalia to Kenya and to entice those refugees already in Kenya to come home.

Four UNHCR 'outposts', administered from Nairobi, were established at various locations roughly one hundred miles from the Kenya-Somalia border, as part of the CBO. The working assumption of the outposts was clear: presence equals protection. By establishing UNHCR offices and providing international civilian staff to complement the UNITAF peacekeepers, the UN believed that it created a safe area for refugee repatriation. It eventually became clear that Southern Somalia was not simply the safely patrolled place and 'preventive zone' that it had been designated. Mere presence did little to convince Somalian refugees in Kenya that it was safe to return. By June 1993, some 12,000 Somalian refugees had returned with the help of UNHCR, but the vast majority remained in Kenyan camps (UNHCR 1993).

Humanitarian operations in both Somalia and Bosnia deployed peacekeepers to ensure the delivery of humanitarian aid. This served to blur the distinction between military and civilian humanitarian operations. On 5 June 1993, a UN vehicle carrying 14 peacekeepers was ambushed by the forces of Mohammed Farah Aideed in Mogadishu, the Somalian capital. When US helicopters then began shooting on Mogadishu in an effort to find or kill Mohammed Farah Aideed, no UN employee-whether peacekeeper or aid 
worker-was safe. Nor was the notion of 'peacekeeping' any longer applicable. UN forces killed Somalian civilians in the attacks, provoking threats of revenge from Aideed supporters. Confrontation between UN and Aideed forces in Mogadishu damaged the UN reputation of neutrality and hastened the peacekeepers' departure. By the end of March 1995, almost all peacekeepers had left Somalia, leaving more than 150,000 Somali refugees in Kenyan camps. While UNHCR designated and mapped the preventive zone as a safe space, the majority of Somali refugees in Kenya stayed put. As in Srebrenica, there was a crucial difference between UN intent and people's perceptions of safety on the ground.

\section{Sri Lanka}

War between the LTTE and the Government of Sri Lanka's armed forces has been raging for twenty years. During the 1983 pogroms, thousands of Tamils in Colombo, the Sri Lankan capital, were murdered, had their property looted and homes burned. The pogroms were retaliation for the killing of thirteen highly ranking (Sinhalese) Sri Lankan soldiers by the LTTE, on the Jaffna Peninsula. The conflict has spawned large-scale displacement within the country and well beyond its borders, where a significant Tamil diaspora has emerged. Statistics suggest that there are more than 800,000 internally displaced persons (Refugee Council 2002). The death toll now exceeds 60,000 . Mass displacement, multiple displacements, long-term displacement, and attacks on communities of displaced persons amid intense militarization across the country present massive challenges to both national and international organizations positioned to address the human needs they generate. Displaced persons exist on both sides of these lines, and encompass Tamil, Sinhala, and Muslim groups, though the vast majority of displaced persons in Sri Lanka are Tamil.

If Northern Iraq's Operation Provide Comfort in 1991 was the first UN Security Council-sanctioned space, it was preceded by a lesser known set of UN-designated safe spaces called 'open relief centres' (ORCs), created by UNHCR in Sri Lanka in November 1990. The idea of a 'safe haven', based on humanitarian legal norms of demilitarized space, to be located on Mannar Island, the closest geographical point to Southern India, was rejected. However, 'the much less ambitious and more pragmatic system of Open Relief Centres' was endorsed as something of an experiment in providing alternatives to formal asylum (Clarance cited in Chimni 1995: 845). Situated in Mannar District in Northern Sri Lanka, three ORCs were established and still operate in the country. Madhu ORC is situated in close proximity to Palimpiddy ORC (about $5 \mathrm{~km}$ north of Madhu); the Pesalai ORC is located on Mannar Island. At the time of their establishment, the first two were located in LTTE-held territory and the latter in a government-held area (Clarance 1993). The largest of the three, located at Madhu, is the focus of the discussion that follows. 
Madhu has quietly provided sanctuary for those displaced from the war over the past dozen years. This ORC was established at the site of an existing Catholic shrine and sanctuary at Madhu, and declared a 'neutral peace zone' by UNHCR at its inception. In an unusual administrative arrangement, the space is officially administered by the church under UNHCR's supervision (Jeyaraj 1999). The ORC was initially conceived of as a temporary place where displaced people on the move could 'freely enter or leave and obtain essential relief assistance in a relatively safe environment' (Athas 1999). Like safe areas in Bosnia and Somalia, the ORC exists as an island of civilian safety and purveyor of material assistance in conditions of war. Unlike the protected areas of Bosnia and Somalia, the ORC at Madhu is a politically neutral space, one which prohibits any weapons or military uniforms or rebel fatigues on site, and one without an international peacekeeping force. From the outset, Madhu and its counterpart ORCs were praised by the British Refugee Council as 'a genuine place of safety in the North' (cited in Clarance 1993: 590). The US Committee for Refugees reported that 'the protection available to displaced persons in the ORCs still is substantially better than anything else to be found in the northeast' (cited in Chimni 1995: 847). The ORCs provided a safe alternative to the camps in Tamil Nadu. In the words of UNHCR's Representative in Sri Lanka at the time, Bill Clarance (1993: 591), 'the Sri Lankan experience helped establish the conceptual and practical basis for UNHCR intervention in situations of conflict which were actually or potentially refugee producing'.

The war in Sri Lanka did generate a role for peacekeepers, albeit not a UNsanctioned one. In 1987, after an accord was reached between the Indian and Sri Lankan governments (one which excluded Tamil political leaders and militant groups like the LTTE), Indian peacekeepers arrived in Northern Sri Lanka to monitor peace and to disarm Tamil militants. 'In theory, the Accord was meant to solve the ethnic conflict. In practice, it was meant to establish Indian hegemony over Sri Lanka' (Institute of Agriculture and Women in Development 1995: 55). The introduction of Indian peacekeepers proved an unpopular move on both sides of the ethnic divide. While the ORC at Madhu was unaffected, fighting ensued between Indian peacekeeping forces and the LTTE until 1990 when the peacekeepers withdrew (p. 55).

What distinguishes the ORC in Northern Sri Lanka from the safe cities of Bosnia and the preventive zone of Somalia are two factors: first, its demilitarized character at the front line of the war and yet its inception outside the rubric of humanitarian law; and second, local consensus among warring factions on its identity as a safe area before UNHCR arrived. The Catholic shrine and church at Madhu is the most sacred in the country (Perera 1998). In 1544, Catholic converts from Mannar Island fled to the Madhu area, following the massacre of some 600 Catholics by the Hindu king of Jaffna. Only a small group, who escaped with a wooden statue of the Virgin Mary, made it safely to Madhu. In the eyes of the survivors, the statue had saved their lives. They erected a church at Madhu, which has become a sacred site of pilgrimage for Catholics of all ethnic backgrounds ever since 
(Perera 1998). In 1982, 250,000 Catholic Sinhalese and 150,000 Catholic Tamils made the pilgrimage to Madhu for the annual festivals. 'Linguistic identities of Sinhala and Tamils were overwhelmed by the over arching feeling of being Christian and Madhu was one place where the ethnic divide was virtually non-existent' (Jeyaraj 1999). When UNHCR landed in Madhu and established a 'zone of peace,' they did so with a tradition of 450 years of sanctuary behind them.

The Church allows no arms on the premises of the 400 acre site. The militant rebel group fighting for an independent Tamil state in Sri Lanka, the LTTE, obliged the Church by agreeing not to recruit members for its cause on the premises. Initially, the LTTE attempted to bear arms in the camp, tax the people to raise funds for its cause, and search for recruits among the population, but 'patiently and quietly the Catholic authorities negotiated with them' (Perera 1999). For more than twelve years, thousands of refugees of different religious backgrounds have lived relatively securely in the ORC, as the conflict in Sri Lanka waxed and waned.

After almost a decade as a 'zone of peace,' however, the open relief centre at Madhu was captured by the Sri Lankan military forces during Operation Rana Gosa [Battle Cry] II on 22 March 1999. In 1999, Madhu was 'cleared' by the government in two senses of the word: first, it took control of the territory, ostensibly from the LTTE, although Madhu had been a sanctuary from both the Sri Lankan Army (SLA) soldiers and LTTE rebels; and second, government forces emptied the camp of thousands of displaced persons, as noted. The government declared that it had 'liberated' Madhu, though Madhu was never occupied by the LTTE. 'Like the Vatican in Italy Madhu Church premises were an oasis of Independence in a desert of LTTE control' (Jeyeraj 1999). The ORC was transformed from a demilitarized neutral space surrounded by LTTE-controlled territory to an armed site under SLA control. With the church grounds occupied, many feared that it would become a target of LTTE attack, thereby increasing insecurity rather than ensuring protection. When church officials objected to uniformed soldiers on the premises, it was explained that they had no change of clothes. Later when the Bishop of Mannar complained to the Sri Lankan president, Chandrika Kumaratunga, she assured him that their presence was only temporary (The Sunday Leader 1999). They were still there on 3 May 1999 when the Defence Minister came to Madhu and declared that it had to be emptied by the end of the month (UNHCR 1999). Without consultation with UNHCR, Madhu was emptied in less than three weeks. ${ }^{6}$ By the end of May, some 4,000 displaced persons were shipped to Jaffna and the remainder relocated to other facilities for the displaced. Although UNHCR reported that houses were 'disassembled' after the refugees left, personal observations in June 1999 confirmed that many homes were burnt and most had lost their roofs.

In November 1999, fighting in the area heightened, and more than 3,500 people sought refuge again in Madhu, but for a short time the shrine ceased to be safe by all accounts. It became the target of both LTTE and army shelling, 
which killed more than 35 civilians inside the Church grounds. The LTTE regained control of the surrounding area once again, and by July 2000, Madhu was again full of displaced persons. The population of the original ORC has fluctuated from a peak of 35,000 in the early 1990 s to a low of about 5,000 in 1993. In March 1999, the ORC at Madhu hosted some 10,000 refugees, and by July 2002, the population had declined only slightly despite the signing of a ceasefire agreement between the government and LTTE in February 2002. These changes illustrate the radical shifts generating displacement in the North, especially in areas close to the frontlines.

Madhu's tradition as a sanctuary and sacred site of pilgrimage continues. In July 2002, the LTTE reached an unprecedented agreement with the Government through the Church authorities, allowing unarmed soldiers in civilian clothing to access Madhu shrine. The Bishop of Mannar responsible for Madhu reported in November 2002 that the number of pilgrims who attended the July and August festivals in 2002 approximated 300,000, and that crowds of up to 2,000 people, mainly from the South, visit the shrine weekly. Conditions prior to 1983 allowed reasonably unfettered access to Madhu shrine for pilgrims, attracting 150,000 and 200,000 , on average, visiting in July and August respectively. This number dropped significantly after 1983, when the LTTE controlled the area surrounding Madhu. Nonetheless, those within this catchment area, some 30,000-50,000 people, still visited Madhu for the nine-day festivals held on 2 July and 15 August during the years of conflict (Bishop of Mannar, personal correspondence, 26 November). Hence, Madhu has a long history of pilgrimage both prior to, and during, the conflict in Sri Lanka.

In contrast to Srebrenica, the ORC at Madhu has operated relatively safely for more than a decade, despite occasional evictions and security incidents. Unlike the preventive zone in Somalia, this safe space has attracted internally displaced persons seeking safety, thus meeting its objectives. The ORC at Madhu is successful, in part, because it builds upon local arrangements of sanctuary and safety. The identity of Madhu as a place has evolved over centuries, and has been politically negotiated at a local level. Despite being recognized by UNHCR, Madhu is first and foremost a shrine and pilgrimage site with local and national connotations. No military force has been required to patrol the borders of such space, despite occasional incursions.

\section{Concluding Remarks: Whose Safety?}

This paper has discussed the antecedents and outcomes of safe areas in three war zones. It has specifically not addressed the (often politicized) statesponsored efforts to create 'humanitarian zones' in Kosovo, 'safe towns' in Chechnya, or regroupment camps in Burundi, where the state is an aggressor and has a strong interest in controlling the movements of marginalized or minority citizen groups. Nonetheless, it is interesting to note these efforts to mimic the international humanitarian discourse, even where conflicts of 
interest are clear: the majority of these protected areas-whether designated by multilateral organizations like the UN or national governments at war with certain segments of their own population-are highly politicized zones where declared intent and actual meaning can be two very different things.

Safe spaces sponsored by the UN Security Council have met with mixed results. The provision of UNITAF troops to Somalia in December 1992 provided a sufficient aura of protection to allow the UN Secretary General to ask UNHCR to create the preventive zone in Southern Somalia. The good intentions of UN Security Council resolution 824 in May 1993 generated, among others, the safe city of Srebrenica. In neither case, were local inhabitants or the parties to the conflict consulted. Whereas the preventive zone in Somalia was a largely ineffectual political palliative, the UN-protected area of Srebrenica was punitive for the displaced persons who sought refuge there. Preventive, palliative, and punitive, the safe havens declared by the UN Security Council saved some lives but failed to protect all that they had promised. What are the policy implications of these various experiments in creating security zones and safe spaces?

While the absence of UN peacekeeping forces and UN political involvement was lamented in Sri Lanka at the inception of the open relief centres (Clarance 1993), the autonomous arrangements afforded by this situation proved advantageous in providing relief and real protection to displaced persons. Militarized safe havens appear to be a contradiction in terms, even when the armed forces are UN peacekeepers. With the exception of Northern Iraq, such militarized arrangements have proven costly and ineffective. Moreover, the establishment of security zones in the first place may have an unintended, but detrimental effect on the status of asylum: the danger is that such spaces are viewed as a substitute for asylum (Chimni 1995). The establishment of safe spaces is about the geopolitical interests of states before the safety of displaced persons, as witnessed in the case of Iraq and ultimately Bosnia-Herzegovina. Hence, every effort to develop appropriate measures that have the consent of the warring parties should be made, leaving the UN Security Council as the last and least desirable venue for decisions on the establishment of safe space. The Security Council has always been a venue for the debate and negotiation of state security; the protection of internally displaced persons is a secondary consideration in this context.

The rules of war and the safe spaces they create, as inscribed in humanitarian law, are less and less relevant as warring factions ignore these consensual arrangements. Dutch peacekeepers in Srebrenica assisted Bosnian Serbs in creating lists of men of fighting age, believing Serb claims that those detained would be questioned as prisoners of war in accordance with the Geneva Conventions. In the end, these lists were used to systematize the murder of between seven and eight thousand Bosnian Muslim men (Leopold 1999). The Geneva Conventions focus on the treatment of combatants in war when they are wounded or captured by enemy forces, and on the protection of civilians. Increasingly, those affected by war are civilians. Whereas most casualties at the 
turn of the nineteenth century occurred among soldiers at the battlefront, civilian deaths and injuries constituted 60 to 80 per cent of casualties at the end of the twentieth century (Boutwell and Klare 2000: 52). Other estimates are as high as 90 per cent (Weiss 1999). Humanitarian law and its provisions may create some useful protected spaces for civilians and wounded combatants, but they are by no means sufficient.

While international humanitarian law is built upon consent in the agreements warring factions forge, there is another distinct scale of negotiating consent in the context of conflict. Consent is not only contractual, in the legal sense, but it is politically constituted through structures of civil society, and in the case of the ORC at Madhu, through places of pilgrimage and worship. Before the war in Sri Lanka, Madhu was a sanctuary; this tradition continues today, albeit in a more formalized manner. The ORC was constituted in a geographical location already inscribed with local connotations of peace. It was built upon this history of sanctuary in Madhu, extending its meaning from a local and national scale to an international one. Sporadic violence, even at Madhu, underscores the fact that all safe spaces within conflict zones are politicized; none is likely to be as neutral as a designated refugee camp in a third country.

\section{Acknowledgements}

I would like to thank Bonny Ling, Jehan Perara, Mala de Alwis, and Bishop Rayappu Joseph, as well as two anonymous reviewers for their various contributions to this work.

1. Refugees fleeing Rwanda to [then] Zaire were accompanied by a number of perpetrators of the genocide against Tutsi in Rwanda. Ample evidence that these perpetrators held refugees in the camps hostage to their wishes has generated much soul-searching among humanitarian organizations that operated in Zaire.

2. Concern was raised that the methodology employed by the group placed humanitarian actors in the compromising position of assuming the role of an obligor under human rights law, a role which [it was emphasized] states alone should play... humanitarian actors could adopt an analytical metholodgy that drew from human rights discourse without undermining the legal obligations of states or purporting to assume the role of obligors' (UN OCHA 1999: 13).

3. The significance of timing, geography, and the political dimensions of humanitarian activities were acknowledged, including a geopolitical analysis of escape routes and possible catchment areas for Albanian Kosovars (UN OCHA 1999: 14-15).

4. Campbell notes that few academic discussions mention ethnic breakdown. My own reading of this is that academic analyses tend to situate the roots of conflict in nationalism, whereas the media have often rendered the problem as 'ethnic'. In a 1992 study commissioned by the Bosnian presidency, over 10 per cent $(56,473)$ of Sarajevo's population still called themselves Yugoslavs, despite the violence. Bosnia had the highest percentage of those who self-identified as Yugoslavs in the national census. Glenny (1992: 142) argues that the move from people identifying as 'Bosnian' 
to identifying as Bosnian Serb, Bosnian Croat, or Bosnian Muslim was the initial step to war in the republic.

Like the Muslims of Sri Lanka, the Slav Muslims of Bosnia are one of the few nations in the world who are nominally identified by their religion and not their language or ethnicity. Bosnian Muslims were recognized as a constituent nation, and not just a minority, within Yugoslavia in 1971, and enshrined in the constitution in 1974 under Tito's rule (Glenny 1992).

5. Between July 1992 and January 1996, UNHCR coordinated the longest running humanitarian airlift in history. It surpassed the Berlin airlift in duration, providing more than 12,000 flights and medical evacuation for over 1,100 casualties of the war (Cutts 1999).

6. This removal of refugees was understood by many political analysts and media commentators as a political move. The government could be looked upon favourably in provincial elections held in April after the gains of Operation Rana Gosa II. As well, Catholics in the south of Sri Lanka could look forward to the possibility of attending the annual festivals once again, which had been inaccessible while the surrounding area was controlled by the LTTE. The government was duly re-elected in December.

ATHAS, I. (1999) 'The Situation Report: Did LTTE Misjudge Operation Rana Gosa II Advance?' The Sunday Times, 28 March.

BOUTWELL, J. and KLARE, M. T. (2000) 'A Scourge of Small Arms', Scientific American, June: 47-55.

CAMPBELL, D. (1999) 'Apartheid Cartography: the Political Anthropology and Spatial Effects of International Diplomacy in Bosnia', Political Geography 18: 395-436.

CHIMNI, B. S. (1995) 'The Incarceration of Victims: Deconstructing Safety Zones', in Al-Nauimi, N. and Meese, R. (eds.) International Legal Issues Arising Under the United Nations Decade of International Law, proceedings of the Qatar International Law Conference 1994. Boston: Martinus Nijhoff.

CLARANCE, B. (1993) 'Protective Structure, Strategy and Tactics: International Protection in Ethnic Conflicts', International Journal of Refugee Law 5(4): 585-596.

CUNLIFFE, S. A. and PUGH, M. (1997) 'The Politicization of UNHCR in the Former Yugoslavia', Journal of Refugee Studies 10: 134-153.

CUTTS, M. (1999) 'The Humanitarian Operation in Bosnia 1992-95: Dilemmas of Negotiating Humanitarian Access', Working Paper No. 8 (New Issues in Refugee Research), UNHCR.

DFAIT (Department of Foreign Affairs and International Trade, Canada) (2000) 'Freedom from Fear: Canada's Foreign Policy for Human Security' URL: http://www.dfait-maeci.gc.ca/ foreignp/HumanSecurity/HumanSecuritysBooklet-e.asp, accessed 10 October 2000.

DUFFIELD, M. (2002) 'Reprising Durable Disorder: Network War and the Securitisation of Aid', in Hettne, B. and Oden, B. (eds.) Global Governance in the 21st Century: Alternative Perspectives on World Order. Stockholm: Expert Group on Development Initiatives, Ministry for Foreign Affairs.

FRELICK, B. (1993) 'Preventing Refugee Flows: Protection or Peril', World Refugee Survey 1993. Washington DC: US Committee for Refugees.

- (1999) 'Down the Rabbit Hole: The Strange Logic of the Internal Flight Alternative', World Refugee Survey 1999. Washington DC: Immigration and Refugee Services of America.

GLENNY, M. (1992) The Fall of Yugoslavia: the Third Balkan War. London/New York: Penguin.

HARLEY, B. (1992) 'Rereading the Maps of the Columbian Encounter', Annals of the Association of American Geographers 82: 522-542.

HINA (news agency) (1998) 'Bosnia: Women hold Protest in Sarajevo over Srebrenica', 11 July (with reports from $\mathrm{BBC}$ Monitoring International Reports).

HOVEY, G. (2001) 'Discontent with Assistance to the Bosnian Return Process', Forced Migration Review 11: 21-22.

HYNDMAN, J. (2000) Managing Displacement: Refugees and the Politics of Humanitarianism. Minneapolis: University of Minnesota Press. 
INSTITUTE OF AGRICULTURE AND WOMEN IN DEVELOPMENT (1995) Women, Transition and Change: A Study of the Impact of Conflict and Displacement on Women in Traditional Society. Colombo: IAWID.

JEYARAJ, D. B. S. (1999) 'The Mystique of Madhu', The Island, 31 March.

KIRKBY, J., KLIEST, T., FRERKS, G., FLIKKKEMA, W. and O'KEEFE, P. (1997) 'UNHCR's Cross-Border Operation in Somalia: The Value of Quick Impact Projects for Refugee Resettlement', Journal of Refugee Studies 10: 181-207.

LEOPOLD, E. (1999) 'UN: World Failed to Confront Evils in Srebrenica', Reuters, 15 November. MAKINDA, S. M. (1993) Seeking Peace From Chaos: Humanitarian Intervention in Somalia. Boulder/London: Lynne Rienner.

NEWLAND, K. (1999) 'The Decade in Review', World Refugee Survey 1999. Washington DC: Immigration and Refugee Services of America.

OUTRAM, Q. (1997) 'Cruel Wars and Safe Havens: Humanitarian Aid in Liberia 1989-1996', Disasters 21: 189-205.

PERERA, J. (1999) 'The Losers at Madhu', The Island, 19 May. (1998) 'Mannar's unique "Zone of Peace", The Island, 25 November.

REFUGEE COUNCIL (2002) 'Sri Lanka: Return to Uncertainty', Sri Lanka Project, London, July; download PDF file at < http://www,refugeecouncil.org.uk/downloads/rc_reports/srilanka_ uncertainty.pdf $>$ (accessed 3 October 2002).

RHODE, D. (1999) 'Slowly Starving Serb Defiance', The New York Times, 18 July.

SHOHAT, E. and STAM, R. (1994) Unthinking Eurocentrism: Multiculturalism and the Media. New York/London: Routledge.

SPARKE, M. (1995) 'Between Demythologizing and Deconstructing the Map: Shawnadithit's New-found-land and the Alienation of Canada', Cartographica 32: 1-21.

THE SUNDA Y LEADER (1999) 'Leave Madhu, Refugees Told', 23 May.

UN OCHA (UN Office for the Coordination of Humanitarian Affairs) (1999) 'Report on the Interagency Expert Consultation on Protected Areas', rapporteur F. Johns, Harvard University, Cambridge MA, 7 April.

UNHCR (1993) The State of the World's Refugees: The Challenge of Protection. Toronto: Penguin. (1999) Personal interview with officer-in-charge for Madhu, 8 June.

WEISS, T. (1999) Military Civilian Interaction: Intervening in Humanitarian Crises. Lanham, Maryland: Rowman and Littlefield. 